\title{
Fungal entomopathogens: a systematic review
}

\author{
Rajat Sharma ${ }^{1 *}(\mathbb{D})$ and Priyanka Sharma ${ }^{2}$
}

\begin{abstract}
Background: Apprehensions about the safety and the environment regarding the insecticidal application against insect infestations have directed our attention toward advancement of biological mediators so that they are assimilated into the concept of integrated pest management stratagems to develop a more practical approach for the management of insect pests. Management of insect pests by making use of biological approaches (such as fungal entomopathogens (EPF) or others which are antagonistic to insect population) provides a substitute approach which reduces the continuous use of chemical amalgams against insect pests.

Main body: The present review provides a framework of the present status of information on EPF as it identifies with their current use as biological control of pest infestations. To utilize a variety of biological control methodologies against insect hosts, it is essential to improve our comprehension of the ecology of EPF and also their role in nature. This article may assist us with understanding the virulence and the virulence factors related with EPF and present the latest developments and accomplishments in the significant field. We focus on recent instances of studies that show the overall patterns in interactions among insect pests and EPF prompting the advancement of epizootics. Also, we sum up the topical discoveries on current status of mycoinsecticides and propose future research needs.
\end{abstract}

Conclusions: As the current mechanism of fungal pathogenesis on insects is moderately slow and needs improvement, there is likewise the requirement for additional comprehension of the interactions among entomopathogens and insect pests so as to grow soundly planned procedures by identifying potential targets and via the improvement of fungal strains for improving the adequacy of these organisms in field applications.

Keywords: Entomopathogenic fungi, Biological control agents, Infection process, Enzymes, Pathogenesis, Host defense, Epizootiology, Mycoinsecticides

\section{Background}

Insect pests are regarded as major deterrents which have accounted for an estimated $10.80 \%$ crop losses on global scale in the era of post green revolution (Dhaliwal et al. 2015). Also, an estimated loss of global annual crop production corresponding to $18-26 \%$ valued at $\$ 470$ billion has been observed recently (Mantzoukas and Eliopoulos 2020). To reduce these losses, insecticides are employed and, as a result, have become an essential method for

\footnotetext{
* Correspondence: sharmarajat.ysp@gmail.com

'Department of Plant Pathology, Dr. YS Parmar University of Horticulture and Forestry, Nauni, Solan, Himachal Pradesh 173230, India

Full list of author information is available at the end of the article
}

suppressing the insect pest infestations due to their abstemiously minimal application effort, high usefulness and expediency (Sharma 2019), but concentrated application of chemicals has brought about the advancement of resistance to either one or even more classes of insecticides in as much as 500 species of pests (Kumar and Kalita 2017).

As a result, the microbial agents (entomopathogens) are viewed as regulatory operators of pest infestations and represent the different species of fungi, viruses, protozoa, and bacteria. Initial studies in reference to entomopathogens were carried out by Agostino Bassi who established that the infectious agent, instigating the 
occurrence of muscardine disease in case of silkworms was Beauveria bassiana Bals. (Hypocreales: Cordycipitaceae). Entomopathogens which befall naturally are significant controlling factors against insect populace (Roy and Cottrell 2008). Tanzini et al. (2001) used the term entomopathogenic for the micro-organisms which regulate the population of insect pests to the levels wherein no economic damage to crop plants is observed. Delgado and Murcia (2011) defined the term in relation to the microbial populace which is proficient in attacking insect pests by incorporating them into their own life cycle and by utilizing them as hosts and also classified these micro-organisms as either facultative or obligate parasites attacking insect pests, having high potential for survival.

Use of microbial population as control agents is not only effective against insect pests but this approach is also environmentally safe and sound for humans (reduced pesticide residues) as well as the non-target organisms. The provocation for the impression of using microbial insect pathogens against insect pests resulted from close examination of the disease of silkworm (Audoin 1837). Afterward, the recommendation to assign microbial insect pathogens against insects came from LeConte (1874) and Pasteur (1874). The first efficacious mass-produced microbial control application on large scale was carried out by Krassilstschik (1888) against Bothynoderes punctiventris (Germar) (Coleoptera: Curculionidae) (sugar beet weevil) by making use of the antagonistic nature of the conidiospores of Metarhizium anisopliae (Metchnikoff) (Hypocreales: Clavipitaceae) in Russia. The credit for examining infectious nature of $M$. anisopliae must be attributed to Elie Metchnikoff, who initially identified the microbial agent as Entomopthora anisopliae against wheat cockchafer, Anisoplia austriaca (Herbst) (Coleoptera: Scarabaeidae).

Out of all the other microbial control agent, EPF are the most imperative due to accumulation of various factors, such as easy distribution, easy manufacturing techniques, availability of large number of already identified strains, and over-expression of exogenous toxins and endogenous proteins (St Leger and Wang 2010). EPF legitimately influence plants more than the most compound pesticides. For instance, endophytic EPF have been archived in many plants, for example, soybeans, wheat, tomatoes, and bananas (Jaber 2015). As per the action mechanism of EPF is concerned, they release spores thereby infecting the body of the insect host. The fungal spores initially propagate on the exterior of host body and later penetrate the host. As a result, death of the insect is inevitable within 4-7 days (conditional on the quantity of spores). Cadaver of the insect serves as the origin of new spores, which further disseminate, and thus, the life cycle of entomopathogenic fungi is continued on new hosts.

EPF also play an important role as either colonizer in rhizosphere (Pava-Ripoll et al. 2011) or plant growth promoters (Jaber and Enkerli 2017). EPF account for the principal number of taxa as in the diverse group of fungi, there are more than 100 genera of EPF comprising of 750-1000 (St Leger and Wang 2010). The multilayered jobs played by EPF could likewise be utilized in a roundabout way as biofertilizers (Jaber and Enkerli 2017), and microbial control specialists in contradiction of both pests and plant infections (Mantzoukas and Grammatikopoulos 2019).

\section{Main text}

\section{Biological control of insects}

Biological control of insect pests with EPF is one of the most desirable and effectual practice involving uses of natural microorganisms, which hinder their activity and can be used as an alternative to the chemical insecticides. There have been some genera of EPF, which are antagonistic toward field, greenhouse, forest, storage, and household pests. These can be incorporated as EPF, for instance Beauveria, Metarhizium, Isaria, Lecanicillium, and Hirsutella. The different species belonging to these genera are target specific and cause infection in many insects. EPF have several biological attributes, such as target-specificity, high reproductively, short generation time, and long survival, which play significant roles in biocontrol of insect pest.

EPF species are mostly isolated from the soil, which protects them from the damaging solar radiation (Meyling and Eilenberg 2007). It has been noted that certain species of Beauveria and Metarhizium can infect and kill insects in soil and also EPF interact with roots of plant for their growth and survival which predominately relies on insects for carbon and not on soil (Inglis et al. 2001).

Endophytic EPF evolve inside the above ground plant tissues and do not produce any perceptible symptoms of infection. Their usage provides numerous advantages consisting of high yield, cost-effectiveness, preservation of beneficial organisms, safe to humans, no harmful effect on environment, and varied biodiversity (Mantzoukas and Eliopoulos 2020). The most commonly applied and naturally occurring EPF endophyte species are Beauveria bassiana, Isaria fumosorosea Wize (Hypocreales: Clavicipitaceae), and Metarhizium anisopliae (Akutse et al. 2013). The endophytic EPF gives protection against numerous pests to host plant and aids to ameliorate plant response through production of compounds and inducing systemic resistance in the host plant. The endophytic EPF and host plant upon colonization secrete several types of chemicals such as secondary metabolites and enzymes. The secondary 
plant metabolites (alkaloids, flavonoids, phenolics, etc.) are produced by the host plant as defense against fungal pathogens, and endophytic EPF produce secondary plant metabolites (benzopyranones, phenolic acids, quinones, and steroids) and enzymes ( $\beta$-1,3-glucanases, chitinases, amylases, laccases, and cellulases) which helps in the interaction between endophyte and plant host (Zaynab et al. 2018).

Historical evidences show the application and efficacy of EPF have been many as the EPF M. anisopliae var acridum has been applied as spray suspension in Africa to control the locusts (Langewald and Kooyman 2007). Spray preparation of hydrophobic conidia was articulated in oil or as wettable agent, and hydrophilic blastopores were formulated as wettable powders. The solar radiation affects the persistence of fungal propagules and their effectiveness can be improved by solar blockers (Inglis et al. 2001). Conidia of M. anisopliae were used on seeds of corn before planting to reduce the damage of wireworms and this increased fresh weight and density of corn (Kabaluk and Ericsson 2007).

\section{Pest control by EPF (approaches)}

Biological control is regarded as a pleasing technique for regulating insects, due to its insignificant environmental impact and inhibiting the development of resistance in vectors. EPF can be employed under three broad biological control approaches, i.e., classical biological control, augmentation, and conservation, by making use of living organisms to suppress the insect population and making it less abundant or less damaging (Hajek 2004).

i. Classical biological control. Classical biological control has been a notable approach that includes the use of a biological control agent to manage the insect pest population. The introduction of an exotic biological control agent for the permanent establishment and long-term sustainable and economical pest control in the new location. The introduction of the Vidalia beetle, Rodolia cardinalis (Mulsant) (Coleoptera: Coccinellidae), from Australia to California in the late 1880s to control the scale insect, Icerya purchase Maskell (Hemiptera: Margarodidae), is the successful example of classical biological control and this approach cannot be better understood without this historical dimension (Abdelghany 2018). The classical biological control needs strong, regional co-ordination of the efforts for the successful management of insectpests. There are few examples of classical biological control with EPF such as Entomophthora maimaiga Humber, Shimazu and Soper (Entomophthorales: Entomophthoraceae), and Zoophthora radicans (Brefeld) (Entomophthorales: Entomophthoraceae) (Shah and Pell 2003). The gypsy moth, Lymantria dispar Linnaeus (Lepidoptera: Erebidae), accidentally introduced in the USA during the 1860s, and E. maimaiga introduced from Japan in the 1900s by placing infected cadavers onto tree trunks and able to control larvae of Gypsy moth which feed on the leaves of many trees (Hajek et al. 2004). The fungal movement of $E$. maimaiga can take place through air-borne conidia (Shah and Pell 2003). Z. radicans were imported from Israel to release in Australia during 1970 to control spotted alfalfa aphid, Therioaphis trifolii f. maculata (Buckton) (Hemiptera: Aphididae), a serious pest of legume plants.

ii. Augmentation. The biological control agents of insect-pests are present in their indigenous pest populations in various circumstances. The natural enemies are either few or active late to restrict the crop damage. There are two strategies of augmentation: Inoculation biological control and inundation biological control (Shah and Pell 2003).

a. Inoculation biological control. The intentional release of a minute amount of fungal biological control agents so that it will multiply and control the pest for an extended period and sustain the pest population below the economic threshold level. The natural enemies are inoculated in small to moderate amounts in the early season of the crop, increase the number of biological control agents, and spread over a period of time before the insect-pest population reaches the maximum potential. The natural enemies are not able to control the pest population permanently at a high population density. After a regular interval of time, the new inoculations must be made for reestablishment because the control is not achieved from released natural enemies (Abdelghany 2018). Soil can be inoculated with mycorrhiza to intensify growth and to advance up a natural process. Beauveria brongniartii inoculated on Barley seeds to produce mycelium and aerial conidia for the control of European cockchafer, Melolontha melolontha Linnaeus (Coleoptera:

Scarabaeidae) in Central Europe (Keller et al. 1999). The consolidated use of Zoophthora radicans Batko (Entomophthorales: Entomophthoraceae) and semiochemicals for the control of Diamondback moth, Plutella xylostella Linnaeus (Lepidoptera: Plutellidae) which is a significant pest of Brassica (Furlong and Pell 2001).

b. Inundation biological control. Inundation biological control includes fungal biological control agent to control the population density of a nasty 
pest. Inundative augmentation involves the release of a massive amount of natural enemy for accelerated short-term control of the insect-pest population (Liu and Li 2004). The control of the pest population is accomplished by the released natural enemies themselves. The pest population is controlled immediately, and the population of both pest and natural enemies diminishes with time. The fungus is employed as a chemical pesticide and different terms are used, i.e., mycopesticide, mycoinsecticide, and biopesticide have been associated with inundation biological control (Abdelghany 2018). Verticillium lecanii (Zimmerman) (Hypocreales: Cordycipitaceae) is adopted to control aphids, whiteflies, and thrips inside the glasshouses in Europe. The mycoinsecticide "Vertalec" is applied against aphids and "Mycotal" against whiteflies and thrips. Beauveria bassiana "Mycotrol" as a commercial mycoinsecticide by Mycotech used against a wide range of insect pests in North America. Metarhizium anisopliae var. acridum commercial product "Green Muscle" effective against locust and grasshopper pests in Africa (Shah and Pell 2003).

\section{iii. Conservation biological control. Conservation}

biological control concerns with the modification of the environment or farming practices to defend and intensify specific entomopathogens to lessen the effect of pests. This approach accommodates to distinguish effective indigenous biological control agents and the selection of practices to conserve and raise their population. The practices which prefer fungal biological control agent may include irrigation and reduction in pesticide usage. The EPF increase in population size and their effective results in a low pest population. Natural enemies include all types of biological regulation: macro-and microorganisms controlling invertebrates, weeds, and plant diseases, including the antagonistic microorganisms responsible for suppressive soils. The conservation biological control approach is correlated to the chief principle of organic farming, which has the protection of the present natural enemies (Shah and Pell 2003 and Abdelghany 2018).

\section{Classification of entomopathogenic fungi}

The classification of fungal organisms has generally relied on their respective ultrastructure (e.g., structure of septum and that of the cell wall) and their morphology (e.g., mechanism of conidiogenesis) as essential standards. The more exact arrangement of EPF into characterized scientific taxa has been accomplished by the examination of their digestive systems (e.g., production of toxins and enzymes and utilization of nutrients) and utilizing genomic analysis (e.g., mtDNA restriction length polymorphism, karyotyping, and rRNA sequences (Khachatourians 1991).

Fungi (true) are presently positioned in four legitimate phyla (Basidiomycota, Ascomycota, Zygomycota, and Chytridiomycota). An artificial phylum, Deuteromycota is also documented comprising of filamentous fungi which exist in anamorphic forms (asexual). It is alleged that the affiliates of this phylum are in fact either basidiomycetes or ascomycetes which have lost their ability to multiply sexually or their sexual structures are not yet described (Alexopoulos et al. 1996). In addition, teleomorphs for various genera of deuteromycete (entomopathogenic) have along these lines been recognized, and a portion of these teleomorphs can likewise be in fact entomopathogenic (e.g., Cordyceps and Torrubiella spp. are identified teleomorphs of Paecilomyces spp. (Samson et al. 1988)).

The oomycetes, once positioned in Mastigomycotina, have now been set in the kingdom of Stramenopila, phylum Oomycota (Barr, 1992). Individuals from this kingdom offer different highlights of monophyletic origin, including a comparative flagellum hair structure and incorporate labyrinthulids, diatoms, and algae (Patterson 1989). The phylogenetic connection among the four phyla of fungi has been proposed, in view of on ultrastructural and morphological highlights, and to a great extent affirmed by resulting analyses of DNA sequence (Alexopoulos et al. 1996) as stated earlier.

Chytridiomycetes might be well-thought-out as the most "crude" organisms since the predecessor of this group diverged primarily and retained flagella and centrioles (Barr, 1992). The zygomycetes diverged before the occurrence of a dikaryotic stage and consistently septate mycelium, which are normal for the basidiomycetes and ascomycetes and the flagella was lost eventually. After the progenitors of basidiomycetes and ascomycetes veered, the basidiomycetes' predecessor developed basidiospores (meiospores ordinarily delivered four for each basidium), in addition to clamp connections and dolipore septa (barrel shaped) and the ascomycetes' progenitors developed ascospores (i.e., meiospores for the most part delivered eight for every ascus). The scientific classification of the Ascomycota is all the more plainly characterized and contains two significant orders: Laboulbeniales (Class: Laboulbeniomycetes) and Hypocreales (Class: Sordariomycetes; subclass: Hypocreomycetidae) (Hibbett et al. 2007).

Hibbett et al. (2007) suggested an arrangement of characterization for all fungal groups dependent on molecular phylogenetic investigations. As stated in the background section, there are 750-1000 EPF, these can 
be found primarily placed in two fundamental groups: phylum Zygomycota, subphylum Entomophthoromycotina, order Entomophthorales, and phylum Ascomycota (subkingdom Dikarya). Nonetheless, the Zygomycota is not an acknowledged phylum inside the re-examined classification. Hence, the Entomophthorales have not been allotted a phylum in the current arrangement. Most of EPF recognized to date have been positioned in the following classes: Zygomycetes (phylum Zygomycota), Hyphomycetes (phylum Deuteromycota), and Pyrenomycetes and Laboulbeniales (phylum Ascomycota) (Samson et al. 1988).

\section{Infection process}

EPF face numerous host challenges in each generation to produce adequate fresh infectious spores to sustain viable populations. The prosperous transmission usually needs the discharge of massive spore numbers and glutinous spore surfaces that enhance adhesion (Vega et al. 2012). The spores germinate and directly invade through the hard exoskeleton of the host insect (Vega et al. 2012). The fungi do not necessitate to be ingested. The EPF commonly invade through the mouthparts or spiracles because of non-sclerotized integument, and smooth penetration (Clarkson and Charnley 1996). The penetration of the epicuticle is directly by germ tubes or infection pegs originated from the underneath of appressoria (Zacharuk 1981). The fungal cells propagate inside the hemocoel, tissues, and muscles of the host's body so that it dies (Vega et al. 2012). The EPF can infect nonfeeding stages such as eggs and pupae. The fungal germlings are steadily crossing distinct environments and counter to the variations invoking biochemical processes and cellular differentiation to form particular morphological structures. The fungal germlings conform to colonize insect tissue and neutralize potential host responses. Infection structures reasonably emerge as a mechanism to surmount host barriers (St Leger and Wang, 2010). The process of infection can be restrained by low humidity conditions because fungus requires high humid conditions for germination and maturity of fungal structures.

The perception of a susceptive host can involve chemical and topographical signals. The cuticle of tobacco hornworm, Manduca sexta Linnaeus (Lepidoptera: Sphingidae), has been used to study the impact of surface topography on appressorium formation. The appressoria developed after extensive germination across the micro folds of the exoskeleton of 1-day fifth-instar larvae. The fungus does not get induction signals from the exoskeleton due to micro folds. Contrastingly, the appressoria germinate close to conidium on 5-day fifthinstar larvae (St Leger and Wang, 2010). The entomopathogen uses the host cadaver for spore production and dispersal under preponderating environmental circumstances (Roy et al. 2006).

Metarhizium spp. and Beauveria spp. belonging to the order Hypocreales are opportunistic hemibiotrophic in nature while fungi belonging to the order Entomophthorales are biotrophic. Metarhizium spp. and Beauveria spp. are entomophagous that infect living insects and saprophagous that invade dead insect corpse. Entomophthorales exterminate their host by the colonization of tissues (Freimoser et al. 2003). Time between application of entomopathogens and revelation to the activity of various parasitoids is vital for the continued existence of the respective parasitoids (Oreste et al. 2015). The application of EPF in context of the time of application has been found to affect the rate of parasitization by a parasitoid. For instance, the treatments of entomopathogens $M$. anisopliae and B. bassi$a n a$ and time of fungal treatment influenced the rate of parasitization by Encarsia formosa Gahan (Hymenoptera: Aphelinidae) against Trialeurodes vaporariorum (Westwood) (Hemiptera: Aleyrodidae) (Oreste et al. 2015).

\section{Fungal invasion}

The process of pathogenesis is initiated by the adhesion of conidia to the insect cuticle. The attachment of fungal propagules to the host exoskeleton is the first and foremost step of the infection process (Sevim et al. 2015). Fungi are heterotrophic organisms that consume the non-chemical compounds provided by different organisms as their chief source of energy. The non-specific adhesion mechanisms involved in binding are controlled by the hydrophobic attributes of the conidial cell wall (Boucias et al. 1988). This process includes interaction among the conidial proteins and the hydrophobic exoskeleton surface of the susceptive insects (Fang et al. 2005). This process happens in three consecutive stages:

1.Adsorption of the spores to the insect exoskeleton

2.Adhesion of pre-germinated spores to the host cuticle

3.Germination and development till appressoria formation (Tellez-Jurado et al. 2009)

The cuticle is a significant impediment to fungal invasion. The insect epicuticle is differentiated into multilayers; the outer epicuticle is mechanically fragile while the inner epicuticle designates toughness, although the enzymes produced by EPF conquer this obstruction (Charnley and St Leger, 1991). The outer epicuticle may be penetrated by an inadequate force and prevent the passage of cuticle-degrading fungal enzymes. Once the epicuticle is passed, penetrant structures may expand laterally propagating penetrant plates. The lateral expansions promote penetration by inducing fractures in the insect cuticle (Brey et al. 1986) and expedite dispersal of the pathogen cuticle-degrading enzymes (Goettel et al. 
1989). In addition, insect epicuticular lipids play important role in binding fungus to the host cuticle (Ferron 1978). The procuticle is impermeable to pathogen secretions; the degree of resistance depends on cuticle thickness and hardening. Insects having heavily sclerotized body segments and cuticular melanisation induced by physical damage or $\beta-1,3$ glucans on the fungal cell wall (Charnley 1989), is common (Butt et al. 1988). Melanisation support to prevent fast-growing pathogens (St Leger 1991), but evaluating these responses in disease resistance is challenging because of inadequate understanding of the amounts of melanin expected to influence infection and how melanin reactions might prevent fungal germination. The inhibitory compounds on the exoskeleton such as phenols, quinones, and lipids lead to the failure of fungal invasion (Kerwin 1984).

The Beauveria, Metarhizium, and Isaria belonging to order Hypocreales have hydrophobic conidia due to hydrophobins (cysteine-rich proteins) in the cell wall while Verticillium lecanii has hydrophilic conidia (Inglis et al. 2001). The conidia of the order Entomophthorales are large and originate from sporangia. The conidia attach themselves to the cuticle and support the adhesion process (Papierok and Hajek 1997). In addition, Neozygites and Zoophthora spp. exhibit elongated capillioconidia and adhere to the exoskeleton through an adhesive droplet (Glare et al. 1985).

The process of adhesion among the spore and the insect cuticle is mediated by the presence of molecules synthesized by the fungus, called adhesins. In M. anisopliae, MAD1 adhesin-like protein is present on the conidial surface to attach to the host surface, but for adhesion to plant surfaces MAD2 is present (Pava-Ripoll et al. 2011). MAD1 adhesin affects germination and blastospore formation, significantly reducing fungus virulence (Wang and St Leger, 2007). The conidium develops and produces penetration structures under promising conditions of temperature, relative humidity, nutritional, and physical requirements in the cuticle. The penetration structures such as appressoria or germ tubes penetrate the host insect through infection peg (Shah and Pell 2003).

Conidiobolus obscurus (Hall \& Dunn), Pandora neoaphidis (Remaud \& Hennebert), Entomophthora planchoniana Cornu, and Batkoa apiculata (Thaxt.) (Entomophthorales: Entomophthoraceae) belong to order Entomophthorales. These can penetrate the cuticle directly from the germ tube without the formation of appressoria (Hajek and Delalibera 2010). B. bassiana requires carbon and fatty acids for the germination of conidia. In addition, insect epicuticular lipids may help in the germination of conidia by providing energy sources and have antifungal properties (Ferron 1978). The hydrolytic enzymes such as proteases, lipases, and chitinases synthesis help to degrade the cuticle and release nutrients for fungus germination (Franco et al. 2011).

M. anisopliae and B. bassiana spores are hydrophobic in nature so they bind to insect cuticle (Holder and Keyhani 2005). The conidia of $M$. anisopliae have cuticledegrading catalysts and the potential to modify the surface of the integument for the attachment. During pregermination development as the conidium dilates, excretion of adhesive mucus takes place which improves the initial hydrophobic interactions among the conidium and cuticular surface (Boucias and Pendland 1991). M. anisopliae strains are more precise toward the scarabid beetles. The cuticle of scarabids has antifungal compounds such as short-chain fatty acids. The EPF must have the capability to endure antifungal compounds for the successful invasion (Boucias and Pendland 1991). The germ tubes of $M$. anisopliae develop appressoria at the surface of the cuticle, infection peg in epicuticle, penetrant hyphae in procuticle, and yeast-like hyphal bodies in the hemocoel. The infection structures emerged as a mechanism to overwhelm host barriers.

M. anisopliae var acridum is specific for the locusts. The conidia may be produced in internal air spaces as the corpse shrivels out under unpropitious circumstances (Wang and St Leger, 2005). Once the EPF invades the cuticle comprised of a polysaccharide network and enters into the hemocoel, this induced biophysical or biochemical interruption in the insect which leads to death of the host insect (Charnley 2003). The fungus will burst out through the exoskeleton of the host insect, producing aerial spores following high relative humidity conditions. The unrestricted germination of the fungus may happen on the corpse of the host insect. The life cycle of the EPF gets completed if sporulated on the cadaver of the host (Samson et al. 1988 and Charnley 2003). Under adverse environmental conditions, resting spores produced within the dead insect may facilitate the fungus to persist for long periods (Samson et al. 1988).

\section{Host response}

After a successful invasion, the EPF proliferate inside the host insect and septicemia occurs. The fungus combats the host-induced restrictions and poisonous compounds additionally; the infection depends on the genetic potential of the pathogen. Structural features such as sclerotization hinder penetration while enzyme inhibitors and tyrosinases generate antimicrobial melanins comprise the frontline defense toward weak pathogens (Gillespie et al. 2000). The protease inhibitors are also present in the hemolymph of infected insects to limit lethal infections. Moreover, the distinct behaviors of the 
host insect can defend. Mycosis provokes physiological symptoms of abnormalities in the insect-like lack of coordination, altered behavior, and paralysis. Death results from a succession of effects that involve the physical deterioration of tissues, toxicity, and dehydration of cells by loss of fluids, and consumption of nutrients (Bustillo 2001). The grasshopper Camnula pellucida (Scudder) (Orthoptera: Acrididae) retrieved from the infection of Entomophaga grylii (Fresenius) (Entomophthorales: Entomophthoraceae) by raising internal body temperature (Carruthers et al. 1992). The prominent virulence constituent in M. anisopliae is PR1 protease, which reduces the time of death by $25 \%$ in Manduca sexta (St Leger et al. 1996). Spores can germinate swiftly in the digestive tract of the insect where the relative humidity is high but digestive fluids degrade germinating hyphae (Charnley 2003).

\section{Virulence enzymes associated with EPF}

The process of pathogenesis is mediated by mechanical force and the enzymatic process. The EPF require virulence enzymes like proteases, peptidases, chitinases, and lipases for entry and successful growth (Khachatourians and Qazi 2008). The proteases and peptidases help in the degradation of the insect cuticle because insect cuticle is composed of chitin and protein. These also aid in the degradation of saprophytic fungi and activate prophenoloxidase in the hemolymph. The fungi B. bassiana, B. brongniartii, Lagenidium giganteum (Schenk) (Oomycota: Lagenidiales), Nomuraea rileyi (Farl.) Samson (Hypocreales: Clavicipitaceae), $M$. anisopliae, and $V$. lecanii have been identified with protein degrading enzymes (Sheng et al. 2006). B. bassiana has subtilisin-like serine endoprotease ( $\operatorname{Pr} 1$ and $\operatorname{Pr} 1 \mathrm{~B})$ and $M$. anisopliae has chymotrypsin (CHY1) (Screen et al. 2001). St Leger et al. (1996) constructed an engineered mycoinsecticides based on $M$. anisopliae by over-expressing the Pr1 toxic protease from $M$. anisopliae genome. This was engineered to enhance the killing speed of $M$. anisopliae. The Pr1 over-expression activates the phenoloxidase system in the hemolymph of Manduca sexta which causes a $25 \%$ reduction in the time of death. The EPF M. anisopliae, B. bassiana, and V. Iecanii have grown in culture containing cuticle of locust produce various hydrolytic enzymes which are active against insect cuticle.

The chitinases (endo and exo-chitinases) play important roles in the cleavage of $\mathrm{N}$-acetylglucosamine. The enzyme helps to break the insect cuticle polymer into monomers. The chitinolytic enzymes were present in $M$. anisopliae, M. flavoviride, and B. bassiana culture supplemented with insect cuticles (St Leger et al. 1996). The enzymatically produced protoplast and cell of $M$. anisopliae have chitinolytic enzymes. These enzyme activities were cell-bound and located in the membrane fraction
(Valadares-Inglis and Peberdy 1997). Bbchit1 encoding gene was present in the $B$. bassiana genome and its amino acid sequence is similar to endochitinase of Streptomyces avermitilis Kim and Goodfellow, S. coelicolor, and T. harzianum (Fang et al. 2005). The epicuticular layer of the insect is made up of non-polar lipids which would be barriers to entomopathogenic fungi without the action of lipases and lipoxygenases (Khachatourians and Qazi, 2008). The growth of EPF is also inhibited by the presence of saturated fatty acid chains. The cuticular lipids affect the conidial germination of B. bassiana and P. fumosoroseus. Also, the nymphs of silver leaf whitefly, $B$. argentifolii, produce a thick coating of long-chain wax esters affecting spore germination (Lord et al. 2002).

The destructive effects of these virulence enzymes on cuticle can be attributed to the structure and enzyme accessibility of protein polymers in the cuticle. The manipulation of pathogen enzymes helps to understand the best cuticle structure and its natural degradation. The characterization of enzyme regulation will enable manipulation of enzyme levels with the help of chemical and biotechnological procedure for insect control (Kramer et al. 1988).

\section{Epizootiology of fungal diseases in insects}

An epizootic of insect fungal diseases is a large number of cases of a disease in a host population. The diseased hosts are usually very abundant during epizootics. Epizootiology of fungal diseases involves the natural history of the disease, phenology of both pathogen and host, impact of the pathogen on host populations, and association of epizootics with weather conditions. The disease development and spread are affected by the host and pathogen populations, the environment, and the impact of human activities. The pathogen having different characteristics includes virulence, dispersal, survival, and inoculum density. The disease incidence depends on the insect age and position in the tree canopy. Abiotic factors such as moisture, temperature, and sunlight may determine whether infection can occur. The moisture helps in the germination and sporulation, and temperature is a limiting factor for disease development. The primary interactions within host-pathogen systems increase, appreciation of community-level influences may aid in understanding, and predicting the development of epizootics. The low-density host populations have less infection, resulting in a host increase (preepizootic phase). Host populations reach high densities, and disease epizootics cause population decline (epizootic phase). The reduced host populations have a high infection, owing to abundant fungi in the environment (postepizootic phase) (Goettel et al. 2005).

The epizootiology of insect pathogenic fungi on insects includes Entomophthora muscae (Cohn) (Entomophthorales: 
Entomophthoraceae) infection on the onion fly, Delia antique Meigen (Diptera: Anthomyiidae), and N. rileyi on Anticarsia gematalis Hubner (Lepidoptera: Noctuidae) in soybean (Carruthers and Haynes 1986). The EPF Erynia radicans and Entomophaga aulicae Batko (Entomophthorales: Entomophthoraceae) produce the highest mortality in spruce budworm, Choristoneura fumiferana (Clemens) (Lepidoptera: Tortricidae), which is a major defoliator in balsam and spruce trees (Perry and Whitfield, 1984). E. grylli causes high mortality in C. pellucida and Melanoplus bivittatus Say (Orthoptera: Acrididae) (Pickford and Riegert 1963). Soil is a complex habitat that harbors flora and fauna. $M$. anisopliae is the most frequent mycopathogens of soil insects, particularly of beetles (Keller and Zimmermann 1989). $M$. anisopliae and B. bassiana are isolated from temperate soils and have a broad host range. B. brongniartii is primarily a pathogen of cockchafers, Melolontha spp., and other Scarabidae (Zimmermann 1992). Epizootics have been found on wireworms, Agrotis spp., and larvae of Amphimallon solstitialis Linnaeus (Coleoptera: Scarabaeidae). On the other hand, under in vitro conditions, various native parasitoids such as Leptopilina heterotoma Thomson (Hymenoptera: Figitidae), Pachycrepoideus vindemiae Rondani (Hymenoptera: Pteromalidae), and Trichopria drosophilae Perkins (Hymenoptera: Diapriidae), have been reported to distinguish and parasitize invasive pest, Drosophila suzukii (Matsumura) (Diptera: Drosophilidae) at varying degrees of adequacy (Ibouh et al. 2019).

Soil is a complex habitat that harbors flora and fauna. $M$. anisopliae is the most frequent mycopathogens of soil insects, particularly of beetles (Keller and Zimmermann 1989). M. anisopliae and B. bassiana are isolated from temperate soils and have a broad host range. Beauveria brongniartii is primarily a pathogen of cockchafers, Melolontha spp., and other Scarabidae (Zimmermann 1992). Epizootics have been found on wireworms, Agrotis spp., and larvae of Amphimallon solstitialis Linnaeus (Coleoptera: Scarabaeidae). Soil is a reservoir for fungi that infect insects present on aerial parts of plants. EPF persist in the soil as mycelium or pseudosclerotia. The spores of $N$. rileyi pathogenic to lepidopteran insects adhere to the leaves of the plant (Ignoffo et al. 1977).

Cordyceps mycoflora is rich in humid and tropical forests and this EPF play a significant role in regulating insect population because of the stable microclimates (Evans 1982). The interactions between virulent and avirulent isolates were complex and are the outcome of dual infection in the leaf-cutting ant, Acromymex echintior Forel (Hymenoptera: Formicidae) (Hughes and Boomsma, 2004). The virulent Aspergillus flavus Link (Eurotiales: Trichocomaceae) dominated when inoculated with $M$. anisopliae. P. neoaphidis infects the sympatric aphids, kills few Acyrthosiphon kondoi Shinji (Hemiptera: Aphididae), and pathogen density is increased, resulting in greater infection of A. pisum (Pickering and Gutierrez 1991). The pathogens and natural enemies' interactions could potentially impact host and pathogen populations. Diatraea saccharalis (Fabricius) (Lepidoptera: Crambidae) parasitized for 1-6 days were inoculated with $M$. anisopliae; the fungus was not harmful to three species of parasitoids (Folegatti and Alves 1987). The fungal infection of hosts in more advanced stages of parasitization impaired fungal development. As the primary interactions increases, the appreciation of community-level influences may help in predicting and understanding the development of epizootics.

\section{Role of EPF in nature}

EPF play important role as plant disease antagonists, rhizosphere colonizers, biocontrol agent of insect-pests, plant growth promoting fungi, and fungal endophytes. The use of natural or modified fungi or bacteria that are antagonists of plant pathogens is considered as biological control. The survival or disease-causing activity of a pathogen is reduced by the production of various metabolites, such as antibiotics, bioactive volatile compounds (e.g., ammonia, hydrogen cyanide, alkyl pyrones, alcohols, acids, esters, ketones and lipids) and enzymes. Some other mechanisms are also involved like competition, antibiosis, hypovirulence, parasitism, and induced systemic resistance (Ownley and Windham 2007). The EPF like B. bassiana, Lecanicillium spp., are antagonistic toward insects but also antagonistic to plant pathogens (Kim et al. 2008). B. bassiana utilizes different antagonism mechanism like antibiosis, competition, and induced systemic resistance (Benhamou and Brodeur 2001).

EPF in the Hypocreales are ubiquitous members of the soil microbiota. The EPF Beauveria, Isaria, and Metarhizium are isolated from soil. The soil not only protects EPF from damaging solar radiation but also from the extremes of temperature (Inglis et al. 2001). The plant rhizosphere has free carbon in abundant amount and exploited by saprotrophic microorganisms (Whipps 2001). EPF interact with plant roots for growth or survival (St Leger and Wang, 2010). The ability of EPF has impaired through the antimicrobial metabolites secreted by microbes present in the soil. The $B$. bassiana applied to control Colorado potato beetle, Leptinotarsa decemlineata (Say) (Coleoptera: Chrysomelidae), but there is low mortality due to increased soil fungistasis levels (Groden and Lockwood 1991). M. anisopliae applied as conidia to corn seeds before planting to reduce damage from wireworms, and increased stand density and fresh weight of field corn (Kabaluk and Ericsson 2007). The fungus which infect internal tissues of above ground plant parts without causing symptoms are known as fungal endophytes (Arnold and Lutzoni 2007). The sum of 
fungal endophytes protects host plants against insect pests (Rudgers et al. 2007). Acremonium, Beauveria, Cladosporium, Clonostachys, and Isaria are some of the EPF (Vega et al. 2008).

EPF are also employed in integrated pest management programs as one of the natural enemies against arthropods including insect pests. Nowadays, the usage of fungal pathogens is drawing special attention as a biological control agent of many insect pests and this approach is reliable, cost-effective, and environmentally safe (Wraight et al. 2001). EPF possesses several attributes that make them a potential candidate to be utilized in the IPM program. Some of the fungi including Beauveria, Metarhizium, Isaria, Lecanicillium, Hirsutella, and Entomophthorales are used as entomopathogens. The $B$. bassiana is effective against lepidopteran, coleopteran, and hemipteran pests. B. bassiana has also been found to be pathogenic in opposition to the larvae of Capnodis tenebrionis (Linnaeus) (Coleoptera: Buprestidae) in laboratory assays as reported by El Khoury et al. (2020) wherein the mortality/transience of $C$. tenebrionis ran between 26 and $76 \%$.

Metarhizium anisopliae is effective against scarab beetle grubs, weevils, termites, and cutworms. L. lecanii used against insects belong to order Hemiptera and Thysanoptera. Paecilomyces lilacinus is used against nematodes (Root-knot, cyst, lesion burrowing) (Skinner et al. 2014). These fungal-based products are harmful to specific insect pests (host-specific) and relatively safe to beneficial insects, non-target organisms, and ecosystems. There is no problem of toxic residues on crops as agrochemicals (Laird et al. 1990). The EPF has been developed or is being evaluated as an integral and essential component of IPM or IDM. Parasitoids have likewise been accounted for to go about as vectors of EPF to the hosts during instances of foraging, as reported by Oreste et al. (2016), wherein Encarsia formosa acted as a passive vector to transfer the fungal propagules from tainted to uninfected populaces due to the virtue of its oviposition and host handling.

\section{Mycoinsecticides: present scenario}

The market of chemical pesticides represents as much as $98 \%$ of the worldwide market of crop protection and consequently, the portion of biopesticides is just $2 \%$. (Anon 2005). A more profound investigation of the share of the overall industry of biopesticides has uncovered that mycoinsecticides have contributed for an exceptionally little division of the market of biopesticide, on the grounds that a large share has been accounted by formulations which are based on the bacterium Bacillus thuringiensis. The development of biopesticides for pest control was at first upheld and contributed by multinational agrochemical organizations yet a large portion of them have opted out since 1980s (Charnley 2003).
Thus, the market is presently directed by small to medium-sized organizations.

Another explanation behind the small share of the overall industry of the fungi as mycoinsecticides is its moderately slow killing rate and an expansion in share of the market value legitimately corresponds to the killing speed (St Leger and Wang 2010). In spite of the fact that these products have the upside of a confined host range, this particularity is likewise one of the restricting elements for their commercial use (Ownley et al. 2004). In this manner, a mycopesticide with a more extensive host extend however with next to zero impact on other natural enemies of useful organisms may have an important commercial advantage in the event that it all the while controls different insect pests and additionally plant infections (Wraight and Carruthers 1999).

However, since the advent of worries over the effect of synthetic compounds, cost of enlisting synthetic concoctions for high value crop plants, development of insecticide resistance, and the developing enthusiasm for "organic/natural" food has now guaranteed a business opportunity for biological agents of pest control, thereby incorporating formulations dependent on EPF. EPF have generally been utilized more broadly on forest pests than on pests of crops (Feng 2003).

Mycopesticide formulations depend on a confined number of fungal species, fundamentally Beauveria bassiana, B. brongniartii, Lecanicillium muscarium, $L$. longisporum, M. anisopliae, Paecilomyces fumosoroseus, and Verticillium lecanii. About $33.9 \%$ of the mycoinsecticidal formulations are based on $B$. bassiana, trailed by M. anisopliae (33.9\%), I. fumosorosea (5.8\%), and B. brongniartii (4.1\%) (Faria and Wraight 2007). However, to build the share of the overall industry of EPF, the killing speed which is the significant deterrent restricting their utilization as mycoinsecticides ought to be enhanced (St Leger and Wang 2010).

As the natural strains of these EPF are deficient in terms of adequate levels of virulence (Rangel et al. 2005), therefore, manipulation at genetic level is important to improve their viability and ecological wellness (Fang et al. 2005) Also, dual infection by different entomopathogens does not affect the mortality of insects. For instance, according to Tarasco et al. (2011) when contrasted with the values which were noted when the two entomopathogens (entomopathogenic nematode Steinernema ichnusae (Nematoda: Steinernematidae) and EPF B. bassiana) were inoculated individually against Galleria mellonella Fabricius (Lepidoptera: Pyralidae), concurrent infection showed neither synergistic nor additive effects.

\section{Future prospects}

Future investigations on EPF should zero in on attempting to comprehend the ecosystem of the fungal growths 
in a setting that centers on their role as antagonists of plant diseases. Most intriguing future prospect in terms of EPF is the possibility to devise stratagems for strain improvement. Attributes which could be tended to include expanded killing power (reduced $\mathrm{LD}_{50}$ ), capacity to start disease at low humidity conditions, upgraded timeframe of realistic usability, and environmental steadiness (for example, temperature tolerance, and resistance against $\mathrm{UV}$ ), augmented kill (reduced $\mathrm{LT}_{50}$ ), improved sporulation during large-scale manufacturing and extension of the host. Lane et al. (1991) suggested that culture conditions impact the attributes of contagious fungal spores and can be controlled to increment mycoinsecticide effectiveness. For instance, Blastospores of $B$. bassiana from carbon-restricted cultures had lower groupings of starch and lipid and were fundamentally less harmful toward the rice green leafhopper than were the blastospores from nitrogen-restricted cultures.

Direct manipulation at genetic level would give upgraded targeting for single genes or clusters of genes, for example, epizootic capability of Beauveria spp. and Metarhizium spp. was enhanced by genetic manipulation, thereby enhancing their saprophytic potential by Wang and St Leger (2005). ESTs and cDNA microarrays were utilized to investigate gene expression during development on a plant root exudate. Genetic manipulation needs the foundation of cloning and transformation frameworks, which have been accomplished for P. fumosoroseus, B. bassiana, and M. anisopliae (Lima et al. 2006).

Keeping the agro-ecosystems aside, EPF are also finding the exploit of their activity against the human and animal pests, for example, work on mosquitoes (Blanford et al. 2005) and tsetse flies (Maniania et al. 2003). Investigations on Brassica root flies (Delia floralis (Fallen) (Diptera: Anthomyiidae) and Delia radicum Linnaeus (Diptera: Anthomyiidae)) (Eilenberg and Meadow 2003), fire ants (Brinkman and Gardner 2004), and mound building termites (Milner 2003) show the assortment of expected targets for mycoinsecticides. Other potential targets researched for utilization of mycoinsecticides incorporate bee parasite Varroa destructor Anderson \& Trueman (Arachnida: Varroidae) (Shaw et al. 2002), blowflies (Wright et al. 2004), parasitic mites (Smith et al. 2000), reduviid bugs such as Triatoma (Lazzarini et al. 2006) and ticks (Samish et al. 2004).

On the other hand, EPF have potential for control of a certain number of insect pests, and it is imperative to distinguish potential targets for mycoinsecticide development and advancement. For instance, beetles and larval pests are every now and again host to fungal diseases however seem to have similarly not many viral and bacterial pathogens. Subsequently, fungi are frequently the microbes of choice for beetle and bug pests (Samson et al. 1988) and the staggering interest has been investigating the potential for B. bassiana and M. anisopliae. A few instances of late examinations are the investigations on the rice water weevil, a pest of rice in North and South America (Chen et al. 2005), the Sunn pest, Eurygaster integriceps Puton (Hemiptera: Scutelleridae), a major insect pest of wheat and barley in West and Central Asia (Parker et al. 2003), and thrips (Ekesi and Maniania 2003).

Investigations into the strain improvement and potential targets for mycoinsecticides will give insights into enhanced disposition of mycoinsecticides for the best pest control and improved development of formulations, detailing to upgrade their adequacy so utilization of the EPF can turn into an essential share of agricultural frameworks as well as the integrated pest management stratagems.

\section{Conclusion}

In the present review, an attempt is made to sum up the utilization of fungal organisms as biopesticides, the authors endeavor and gather the information about the EPF as biocontrol operators. We gather knowledge on the past and present researches about EPF to investigate approaches to improve their capacities. The action mechanism of infection by the EPF is not only complex but specialized as well. Therefore, there is a need to acquire the knowledge of insect-fungus interaction as the host-pathogen interactions are basic determinants of pathogenicity and epizootic turn of events. Molecular and biochemical examinations of host-pathogen interactions are characterizing those properties yielding expanded pathogenicity and are focused on the management of explicit fungal processes. Examinations at the level of an organism include investigations of the turn of events and activity of different phases of host and pathogen, which are regularly in association with variations in natural conditions of the ecosystem. The utilization of EPF in agro-ecosystems has expanded as of late because of the extraordinary potential they have in the field of pest management, speaking to a productive option in contrast to the utilization of synthetic chemical compounds, which are viewed as exceptionally hurtful to the soundness of man and environment alike. Understanding the components engaged with the process of infection, will permit the development of new organic/ biological formulations that are compelling for field use and securing the beneficial species of insects. Be that as it may, there are various limitations on the utilization of EPF as an insecticide, for instance, the potential outcomes of contamination with mycotoxins such as, citrinin, zearalenone, aflatoxins, fumonisins, and trichothecenes delivered by various saprophytic fungi as environmental toxins cannot be precluded. Other 
limitations include the facts that not only the application of EPF must coincide with high relative humidity conditions but also there is a need for a period where no chemical fungicide application has taken place. Moreover, the inoculum has short timeframe of realistic usability and the formulation requires $2-3$ weeks to kill the insects. Along these lines, novel thoughts and speculation need to rise which will further assist in building up the fungi's abilities as biocontrol specialists.

\section{Abbreviations \\ mtDNA: Mitochondrial deoxyribonucleic acid; rRNA: Ribosomal ribonucleic acid; PR1: Pathogenesis related protein-1; IPM: Integrated pest management; IDM: Integrated disease management; LD: Lethal dose; LT: Lethal time; EST: Expressed sequence tag; cDNA: Complementary deoxyribonucleic acid \\ Acknowledgements \\ Not applicable \\ Authors' contributions \\ Both RS and PS researched and reviewed the existing literature on the topic at hand. RS worked on the "Background," "Classification of Entomopathogenic Fungi," "Mycoinsecticides: Present Scenario," "Future prospects," and "Conclusion" sections of the manuscript. PS worked on sections titled "Biological Control of Insects," "Pest Control by EPF (Approaches)," "Infection process," "Virulence enzymes associated with EPF," "Epizootiology of fungal diseases in insects," and "Role of EPF in Nature." RS contributed to the critical review and editing of the manuscript. Both authors read and approved the final manuscript.}

\section{Funding}

Not applicable

\section{Availability of data and materials}

Not applicable

\section{Declarations}

Ethics approval and consent to participate

Not applicable

\section{Consent for publication}

Not applicable

\section{Competing interests}

The authors declare that they have no competing interests.

\section{Author details}

'Department of Plant Pathology, Dr. YS Parmar University of Horticulture and Forestry, Nauni, Solan, Himachal Pradesh 173230, India. ${ }^{2}$ Department of Entomology, Dr. YS Parmar University of Horticulture and Forestry, Nauni, Solan, Himachal Pradesh 173230, India.

Received: 8 January 2021 Accepted: 15 March 2021

Published online: 23 March 2021

\section{References}

Abdelghany TH (ed) (2018) Entomopathogenic fungi and their role in biological control. OMICS International, USA, pp 3-27

Akutse KS, Maniania NK, Fiaboe KKM, Van den Berg J, Ekesi S (2013) Endophytic colonization of Vicia faba and Phaseolus vulgaris (Fabaceae) by fungal pathogens and their effects on the life-history parameters of Liriomyza huidobrensis (Diptera: Agromyzidae). Fungal Ecol 6:293-301

Alexopoulos CJ, Mims CW, Blackwell M (1996) Introductory mycology, 4th edn. Wiley, New York, p 880

Anonymous (2005) Spotlight on biopesticides. Crop Protection 184. (http://www. cropprotection-monthly.co.uk). Accessed 18 November 2020.

Arnold AE, Lutzoni F (2007) Diversity and host range of foliar fungal endophytes: are tropical leaves biodiversity hotspots? Ecology 88:541-549
Audoin V (1837) Nouvelles expe'riences sur la nature de la maladie contagieuse qui attaque les Vers a' soie, et qu'on de'signe sous le nom de Muscardine. Ann sci Nat 8:257-270

Barr DJS (1992) Evolution and kingdoms of organisms from the perspective of a mycologist. Mycologia 84:1-11

Benhamou N, Brodeur J (2001) Pre-inoculation of Ri T-DNA transformed cucumber roots with the mycoparasite, Verticillium lecanii, induces host defense reactions against Pythium ultimum infection. Physiol Mol Plant Pathol 58:133-146

Blanford S, Chan BHK, Jenkins N, Sim D, Turner RJ, Read AF, Thomas MB (2005) Fungal pathogen reduces potential for malaria transmission. Science 308 : 1638-1641

Boucias DG, Pendland JC (1991) Attachment of mycopathogens to cuticle: the initial event of mycosis in arthropod hosts. In: Cole GT, Hoch HC (eds) The Fungal Spore and Disease Initiation in Plants and Animals. Plenum Press, New York, pp 101-128

Boucias DG, Pendland JC, Latge JP (1988) Nonspecific factors involved in attachment of entomopathogenic Deuteromycetes to host insect cuticle. Appl Environ Microbiol 54:1795-1805

Brey PT, Latge JP, Prevost MC (1986) Integumental penetration of the pea aphid, Acyrthosiphon pisum, by Conidiobolus obscurus. J Invertebr Pathol 48:34-41

Brinkman MA, Gardner WA (2004) Red imported fire ant (Hymenoptera: Formicidae) control in nursery pots treated with Beauveria bassiana and bifenthrin. J Entomol Sci 39:75-187

Bustillo A (2001) Hongos en insectos y poszibilidades de uso en el control biológico de plagas en Colombia. In: Seminario Uso de entomopatógenos en Colombia. Sociedad Colombiana de Entomología, Bogotá, pp 30-53

Butt TM, Wraight SP, Galaini-Wraight S, Humber RA, Roberts DW, Soper RS (1988) Humoral encapsulation of the fungus Erynia radicalls (Entomophthorales) by the potato leafhopper Empoasca fabae (Homoptera: Cicadellidae). J Vertebr Pathol 52:49-56

Carruthers RI, Haynes DL (1986) Temperature, moisture, and habitat effects on Entomophthora muscae (Entomophthorales, Entomophthoraceae) conidial germination and survival in the onion agroecosystem. Environ Entomol 15: $1154-1160$

Carruthers RI, Larkin TS, Firstencel H, Feng Z (1992) Influence of thermal ecology on the mycosis of a range land grasshopper. Ecology 73:190-204

Charnley AK (1989) Mechanisms of fungal pathogenesis in insects. In: Whipps JM, Lumsden RD (eds) The biotechnology of fungi for improving plant growth. Cambridge Univ. Press, London, pp 85-125

Charnley AK (2003) Fungal pathogens of insects: cuticle degrading enzymes and toxins. Adv Bot Res 40:241-321

Charnley AK, St Leger RJ (1991) The role of cuticle degrading enzymes in fungal pathogenesis in insects. In: Cole GT, Hoch HC (eds) The fungal spore and disease initiation in plant and animals. Plenum Press, New York, pp 267-286

Chen H, Chen ZM, Zhou YS (2005) Rice water weevil (Coleoptera: Curculionidae) in mainland China: invasion, spread and control. Crop Protect 24:695-702

Clarkson JM, Charnley AK (1996) New insights into the mechanisms of fungal pathogenesis in insects. Trends Microbiol 4:197-203

Delgado PAM, Murcia OP (2011) Hongos entomopatógenos: Uma alternativa para la obtención de Biopesticidas. Ambi-Agua 6:77-90

Dhaliwal GS, Jindal V, Mohindru B (2015) Crop losses due to insect pests: global and Indian scenario. Indian J Entomol 77:165-168

Eilenberg J, Meadow R (2003) Fungi for biological control of Brassica root flies, Delia radicum, and Delia floralis. In: Upadhyay RK (ed) Advances in microbial control of insect pests. Kluwer, New York, pp 181-192

Ekesi S, Maniania NK (2003) Metarhizium anisopliae: an effective biological control agent for the management of thrips in horti-and floriculture in Africa. In: Upadhyay RK (ed) Advances in microbial control of insect pests. Kluwer, New York, pp 165-180

El Khoury Y, Noujeim E, Ravlic J, Oreste M, Addante R, Nemer N, Tarasco E (2020) The effect of entomopathogenic nematode and fungi against four xylophagous pests. Biocontrol Sci Technol 30(9):983-995

Evans HC (1982) Entomogenous fungi in tropical forest ecosystems: an appraisal. Ecol Entomol 7:47-60

Fang W, Leng B, Xiao Y, Jin K, Ma J, Fan Y, Feng J, Yang X, Zhang Y, Pei Y (2005) Cloning of Beauveria bassiana chitinase gene Bbchit1 and its application to improve fungal strain virulence. Appl Environ Microbiol 71:363-370

Faria MR, Wraight SP (2007) Mycoinsecticides and Mycoacaricides: a comprehensive list with worldwide coverage and international classification of formulation types. Biol Control 43:237-256 
Feng MG (2003) Microbial control of insect pests with entomopathogenic fungi in China: a decade's progress in research and utilization. In: Upadhyay RK (ed) Advances in microbial control of insect pests. Kluwer, New York, pp 213-234

Ferron P (1978) Biological control of insect pests by entomogenous fungi. Annu Rev Entomol 23:409-442

Folegatti MEG, Alves SB (1987) Interaction between the fungus Metarhizium anisopliae (Metsch.) Sorok., and the main parasitoids of the sugar cane borer, Diatraea saccharalis (Fabr.). An Soc Entomol Brasil 16:351-362

Franco K, Rodríguez S, Cervantes J, Barranco J (2011) Enzimas y toxinas de hongos entomopatógenos, su aplicación potencial como insecticidas y fungicidas. Sociedades Rurales Producción y Medio Ambiente 11:22

Freimoser FM, Screen S, Bagga S, Hu G, St. Leger RJ (2003) Expressed sequence tag (EST) analysis of two subspecies of Metarhizium anisopliae reveals a plethora of secreted proteins with potential activity in insect hosts. Microbiology 149:1-9

Furlong MJ, Pell JK (2001) Horizontal transmission of entomopathogenic fungi by the diamond back moth. Biol Control 22:288-289

Gillespie JP, Bailey AM, Cobb B, Vilcinskas A (2000) Fungi as elicitors of insect immune responses. Arch Insect Biochem Physiol 44:49-68

Glare TR, Chilvers GA, Milner RJ (1985) Capilliconidia as infective spores in Zoophthora phalloides (Entomophthorales). Trans Brit Mycol Soc 85:463-470

Goettel S, Eilenberg J, Glare T (2005) Entomopathogenic fungi and their role in the regulation of insect populations. In: Gilbert LB, latrou K (eds) Comprehensive molecular insect science. Elsevier Pergamon, Oxford, pp 361-406

Groden E, Lockwood JL (1991) Effects of soil fungistasis on Beauveria bassiana and its relationship to disease incidence in the Colorado potato beetle, Leptinotarsa decemlineata, in Michigan and Rhode Island soils. J Invertebr Pathol 57:7-16

Goettel MS, St Leger RJ, Rizzo NW, Staples RC, Roberts DW (1989) Ultrastructural localization of a cuticle degrading protease produced by the entomopathogenic fungus Metarhizium anisopliae during penetration of host (Manduca sexta) cuticle. J Gen Microbiol 135:2233-2239.

Hajek A (2004) Natural enemies: an introduction to biological control. Cambridge University Press, Cambridge, p 378

Hajek AE, Delalibera I (2010) Fungal pathogens as classical biological control agents against arthropods. Biol Control 55:147-158

Hibbett DS, Binder M, Bischoff JF, Blackwell M, Cannon PF (2007) A higher-level phylogenetic classification of the Fungi. Mycol Res 111:509-547

Holder DJ, Keyhani NO (2005) Adhesion of the entomopathogenic fungus Beauveria (Cordyceps) bassiana to substrata. Appl Environ Microbiol 71:5260-5266

Hughes WOH, Boomsma JJ (2004) Let your enemy do the work: within-host interactions between two fungal parasites of leaf-cutting ants. Proc R Soc Lond Series B-Biol Sci 271:104-106

Ibouh K, Oreste M, Bubici G, Tarasco E, Rossi Stacconi MV, loriatti C, Verrastro V, Anfora G, Baser N (2019) Biological control of Drosophila suzukii: efficacy of parasitoids, entomopathogenic fungi, nematodes and deterrents of oviposition in laboratory assays. Crop Prot 125:104897

Ignoffo CM, Garcia C, Hostetter DL, Pinnel RE (1977) Laboratory studies of the entomopathogenic fungus Nomuraea rileyi: soil born contamination of soybean seedlings and dispersal of diseased larvae of Trichoplusia ni. J Invertebr Pathol 29:147-152

Inglis GD, Goettel MS, Butt TM, Strasser (2001) Use of hyphomycetous fungi for managing insect pests. In: Butt TM, Jackson CW, Magan N (eds) Fungi as Biocontrol Agents: Progress. Problems and Potential. CABI International/ AAFC, Wallingford, pp 23-69

Jaber LR (2015) Grapevine leaf tissue colonization by the fungal entomopathogen Beauveria bassiana s.l. and its effect against downy mildew. Biol Control 60:103-112

Jaber LR, Enkerli J (2017) Fungal entomopathogens as endophytes: can they promote plant growth? Biocontrol Sci Technol 27:28-41

Kabaluk JT, Ericsson JD (2007) Seed treatment increases yield of field corn when applied for wireworm control. Agron J 99:1377-1381

Keller S, Zimmermann G (1989) Mycopathogens of soil insects. In: Wilding N, Collins NM, Hammond PM, Webber JF (eds) Insect-fungus interactions. Academic Press, London, pp 239-270

Keller S, Schweizer C, Shah P (1999) Differential susceptibility of two melolontha populations to infections by the fungus Beauveria brongniartii. Biocontrol Sci Technol 9:441-446

Kerwin JL (1984) Fatty acid regulation of the germination of Erynia variabilis conidia on adults and puparia of the lesser housefly, Fannia canicularis. Can J Microbiol 30:158-161
Khachatourians GG (1991) Physiology and genetics of entomopathogenic fungi. In: Arora DK, Ajello L, Mukerji KG (eds) Handbook of applied mycology, Humans, animals, and insects. Marcel Dekker Inc, New York, pp 613-661

Khachatourians GG, Qazi S (2008) Entomopathogenic fungi. In: Brakhage AA, Zipfel PF (eds) Biochemistry and molecular biology, human and animal relationships, 2nd edn. The Mycota VI, Springer-Verlag, Berlin, pp 33-61

Kim JJ, Goettel MS, Gillespie DR (2008) Evaluation of Lecanicillium longisporum, Vertalec for simultaneous suppression of cotton aphid, Aphis gossypii, and cucumber powdery mildew, Sphaerotheca fuliginea, on potted cucumbers. Biol Control 45:404-409

Kramer KJ, Hopkins TL, Shaefer J (1988) Insect cuticle structure and metabolism. In: Hedin P, Menn J, Hollingworth R (eds) Biotechnology for Crop Protection. American Chemical Society Symposium Series 379, Washington, DC, pp 160 185

Krassilstschik J (1888) La production industrielle des parasites ve'ge'taux pour la destruction des insectes nuisibles. Bulletin Biologique de la France et de la Belgique. 19:461-472

Kumar D, Kalita P (2017) Reducing postharvest losses during storage of grain crops to strengthen food security in developing countries. Foods 6(1):8

Laird M, Lacey LA, Davidson EW (eds) (1990) Safety of microbial insecticides. CRC Press, Boca Raton, Florida

Lane BS, Trinci AP, Gillespie AT (1991) Influence of cultural conditions on the virulence of conidia and blastospores of Beauveria bassiana to the green leafhopper, Nephotettix virescens. Mycol Res 95:829-833

Langewald J, Kooyman C (2007) Green muscle, a fungal biopesticide for control of grasshoppers and locusts in Africa. In: Vincent C, Goettel MS, Lazarovits G (eds) Biological Control: A Global Perspective. CABI International/AAFC, Wallingford, pp 311-318

Lazzarini GMJ, Rocha LFN, Luz C (2006) Impact of moisture on in vitro germination of Metarhizium anisopliae and Beauveria bassiana and their activity on Triatoma infestans. Mycol Res 110:485-492

LeConte $J$ (1874) Hints for the promotion of economic entomology. In: Proceedings of the American Association for the Advancement of Science, vol 22, pp 10-22

Liu XZ, Li SD (2004) Fungal secondary metabolites in biological control of crop pests. In: An ZQ (ed) Handbook of industrial mycology. Marcel Dekker Inc, New York, pp 723-747

Lord JC, Anderson S, Stanley DW (2002) Eicosanoids mediate Manduca sexta cellular response to the fungal pathogen Beauveria bassiana: a role for the lipoxygenase pathway. Arch Insect Biochem Physiol 51:46-54

Maniania NK, Laveissiere C, Odulaja A, Ekesi S, Herren HR (2003) Entomopathogenic fungi as potential biocontrol agents for tsetse flies. In: Upadhyay RK (ed) Advances in microbial control of insect pests. Kluwer, New York, pp 145-164

Mantzoukas S, Eliopoulos PA (2020) Endophytic entomopathogenic fungi: a valuable biological control tool against plant pests. Appl Sci 10:360

Mantzoukas S, Grammatikopoulos G (2019) The effect of three entomopathogenic endophytes of the sweet sorghum on the growth and feeding performance of its pest, Sesamia nonagrioides larvae, and their efficacy under field conditions. Crop Prot 127:104952

Meyling N, Eilenberg J (2007) Ecology of the entomopathogenic fungi Beauveria bassiana and Metarhizium anisopliae in temperate agroecosystems: potential for conservation biological control. Biol Control 43:145-155

Milner RJ (2003) Application of biological control agents in mound building termites (Isoptera: Termitidae) - experiences with Metarhizium in Australia. Sociobiology 41:419-428

Oreste M, Baser N, Bubici G, Tarasco E (2015) Effect of Beauveria bassiana strains on the Ceratitis capitata - Psyttalia concolor system. Bull Insectol 68(2):265272

Oreste M, Bubici G, Poliseno M, Tarasco E (2016) Effect of Beauveria bassiana and Metarhizium anisopliae on the Trialeurodes vaporariorum-Encarsia formosa system. J Pest Sci 89(1):153-160

Ownley BH, Pereira RM, Klineman WE, Quigley NB Leckie BM (2004) Beauveria bassiana, a dual-purpose biocontrol organism, with activity against insect pests and plant pathogens. In: Lartey RT, Caeser A (eds.) Emerging Concepts in Plant Health Management, Research Signpost, Kerala, pp 255-269.

Ownley BH, Windham M (2007) Biological control of plant pathogens. In: Trigiano RN, Windham MT, Windham AS (eds) Plant pathology: concepts and laboratory exercises, 2nd edn. CRC Press, Boca Raton, pp 423-436

Papierok B, Hajek AE (1997) Fungi: Entomophthorales. In: Lacey LA (ed) Manual of Techniques in Insect Pathology. Academic Press, London, pp 187-212 
Parker BL, Skinner M, Costa SD, Gouli S, Reid W, El Bouhssini M (2003) Entomopathogenic fungi of Eurygaster integriceps Puton (Hemiptera: Scutelleridae): collection and characterization for development. Biol Control 27:260-272

Pasteur L (1874) Observations (au sujet des conclusions de M. Dumas) relatives' au phylloxera. Comptes rendus hebdomadaires des se'ances de l'Acade'mie des Sciences 79:1233-1234

Patterson DJ (1989) Stramenopiles: chromophytes from a protistan perspective. In: Green JC, Leadbeater BSC, Diver WL (eds) The chromophyte algae: problems and perspectives. Clarendon Press, Oxford, pp 357-379

Pava-Ripoll M, Angelini C, Fang W, Wang S, Posada FJ, St Leger R (2011) The rhizosphere competent entomopathogen Metarhizium anisopliae expresses a specific subset of genes in plant root exudate. Microbiology 157:47-55

Perry DF, Whitfield GH (1984) The interrelationships between microbial entomopathogens and insect hosts: a system study approach with particular reference to the Entomophthorales and the Eastern spruce budworm. In: Anderson JM, Rayner ADM, Walton D (eds) Animal-microbial interactions. Cambridge University Press, Cambridge, pp 307-331

Pickering J, Gutierrez AP (1991) Differential impact of the pathogen Pandora neoaphidis (R. \& H.) Humber (Zygomycetes: Entomophthorales) on the species composition of Acyrthosiphon aphids in alfalfa. Can Entomol 123:315-320

Pickford R, Riegert PW (1963) The fungus disease caused by Entomophthora grylli Fres., and its effects on grasshopper populations in Saskatchewan in 1963. Can Entomol 96:1158-1166

Rangel DEN, Braga GUL, Anderson AJ, Roberts DW (2005) Variability in conidial thermotolerance of Metarhizium anisopliae isolates from different geographic origins. J Invertebr Pathol 88:116-125

Roy HE, Cottrell TE (2008) Forgotten natural enemies: interactions between coccinellids and insect-parasitic fungi. Eur J Entomol 105:391-398

Roy HE, Steinkraus D, Eilenberg J, Hajek AE, Pell JK (2006) Bizarre interactions and endgames: entomopathogenic fungi and their arthropod hosts. Annu Rev Entomol 51:331-357

Rudgers JA, Holah J, Orr SP, Clay K (2007) Forest succession suppressed by an introduced plant-fungal symbiosis. Ecology 88:18-25

Samish M, Ginsberg H, Glazer I (2004) Biological control of ticks. Parasitology 129: 389-403

Samson RA, Evans HC, Latgé JP (1988) Atlas of entomopathogenic fungi. Springer, Berlin

Screen SE, Hu G, St Leger RJ (2001) Transformants of Metarhizium anisopliae sf. anisopliae overexpressing chitinase from Metarhizium anisopliae sf. Acridum show early induction of native chitinase but are not altered in pathogenicity to Manduca sexta. J Invertebr Pathol 78:260-266

Sevim A, Sevim E, Demirbağ Z (2015) General biology of entomopathogenic fungi and their potential to control pest species in Turkey (Entomopatojenik fungusların genel biyolojileri ve Türkiye'de zararlı böceklerin mücadelesinde kullanılma potansiyelleri). Erzincan Üniversitesi Fen Bilimleri Enstitüsü Dergisi 8:115-147

Shah PA, Pell JK (2003) Entomopathogenic fungi as biological control agents. Appl Microbiol Biotechnol 61:413-423

Sharma R (2019) Analytical concept of fungicide resistance: a review. Int J Curr Microbiol Appl Sci 8:1672-1684

Shaw KE, Davidson G, Clark SJ, Ball BV, Pell JK, Chandler D, Sunderland KD (2002) Laboratory bioassays to assess the pathogenicity of mitosporic fungi to Varroa destructor (Acari: Mesostigmata), an ectoparasitic mite of the honeybee, Apis mellifera. Biol Control 24:266-276

Sheng J, An K, Deng C, Li W, Bao X, Qiu D (2006) Cloning a cuticle-degrading serine protease gene with biologic control function from Beauveria brongniartii and its expression in Escherichia coli. Curr Microbiol 53:124-128

Skinner M, Parker BL, Kim JS (2014) Role of entomopathogenic fungi. In: Abrol DP (ed) Integrated pest management. Academy Press, London, pp 169-191

Smith KE, Wall R, French NP (2000) The use of entomopathogenic fungi for the control of parasitic mites, Psoroptes spp. Vet Parasitol 92:97-105

St Leger RJ, Wang C (2010) Genetic engineering of fungal biocontrol agents to achieve efficacy against insect pests. Appl Microbiol Biotechnol 85:901-907

St Leger RJ, Joshi L, Bidochka MJ, Roberts DW (1996) Construction of an improved mycoinsecticide overexpressing a toxic protease. In: Proceedings of the National Academy of sciences of the United States of America, vol 93, pp 6349-6354

St Leger RJ (1991) Integument as a Barrier to Microbial Infections. In: Binnington K, Retnakaran A (eds) The Physiology of Insect Epidermis. Commonwealth Scientific and Industrial Research Organization, Melbourne, pp 286-308.
Tanzini M, Alves S, Setten A, Augusto N (2001) Compatibilidad de agent estensoactivos com Beauveria bassiana y Metarhizium anisopliae. Manejo Integrado de Plagas 59:15-18

Tarasco E, Santiago Alvarez C, Triggiani O, Quesada Moraga E (2011) Laboratory studies on the competition for insect haemocoel between Beauveria bassiana and Steinernema ichnusae recovered in the same ecological niche. Biocontrol Sci Technol 21(6):693-704

Tellez-Jurado A, Cruz RMG, Flores MY, Asaff TA, Arana Cuenca A (2009) Mecanismos de acción y respuesta en la relación de hongos entomopatógenos e insectos. Revista Mexicana de Micología 30:73-80

Valadares-Inglis MC, Peberdy JF (1997) Location of chitinolytic enzymes in protoplasts and whole cells of the entomopathogenic fungus Metarhizium anisopliae. Mycol Res 101:1393-1396

Vega FE, Posada F, Aime MC, Pava-Ripoll M, Infante F, Rehner SA (2008) Entomopathogenic fungal endophytes. Biol Control 46:72-82

Vega FE, Meyling N, Luangsa-Ard J, Blackwell M (2012) Fungal entomopathogens. Insect Pathology 2:171-220

Wang C, St Leger RJ (2005) Developmental and transcriptional responses to host and nonhost cuticles by the specific locust pathogen Metarhizium anisopliae var. acridum. Eukaryot Cell 4:937-947

Wang C, St Leger RJ (2007) The MAD1 adhesin of Metarhizium anisopliae links adhesion with blastospore production and virulence to insects, and the MAD2 adhesion enables attachment to plants. Eukaryot Cell 6:808-816

Whipps JM (2001) Microbial interactions and biocontrol in the rhizosphere. J Exp Bot 52:487-511

Wraight SP, Carruthers RI (1999) Production, delivery, and use of mycoinsecticides for control of insect pests of field crops. In: Hall FR, Menn JJ (eds) Biopesticides: Use and delivery. Humana Press, Totowa, pp 233-269

Wraight SP, Jackson MA, de Kock SL (2001) Production, stabilization and formulation of fungal biological agents. In: Butt TM, Jackson C, Magan N (eds) Fungi as Biocontrol Agents. CABI, Wallingford, pp 253-287

Wright C, Brooks A, Wall R (2004) Toxicity of the entomopathogenic fungus, Metarhizium anisopliae (Deuteromycotina: Hyphomycetes) to adult females of the blowfly Lucilia sericata (Diptera: Calliphoridae). Pest Manag Sci 60:639644

Zacharuk RY (1981) Fungal diseases of terrestrial insects. In: Davidson EW (ed) Pathogenesis of Invertebrate Microbial Diseases. Allanheld, Osmun and Co Totowa, pp 367-402

Zaynab M, Fatima M, Abbas S, Sharif Y, Umair M, Zafar MH, Bahadar K (2018) Role of secondary metabolites in plant defense against pathogens. Microb Pathog 124:198-202

Zimmermann G (1992) Use of the fungus Beauveria brongniartii for control of the European cockchafer, Melolontha spp. in Europe. In: Jackson TA, Glare TR (eds) Use of pathogens in scarab pest management. Intercept, Andover, pp 199-208

\section{Publisher's Note}

Springer Nature remains neutral with regard to jurisdictional claims in published maps and institutional affiliations.

\section{Submit your manuscript to a SpringerOpen ${ }^{\circ}$ journal and benefit from:}

- Convenient online submission

- Rigorous peer review

- Open access: articles freely available online

- High visibility within the field

- Retaining the copyright to your article

Submit your next manuscript at $>$ springeropen.com 